\title{
Efektivitas Ekstrak Andaliman (Zanthoxylum Acanthopodium Dc.) untuk Meningkatkan Daya Tahan Oksidatif Minyak Goreng
}

\author{
The Effecteness of Andaliman Extract (Zanthoxylum acanthopodium DC.) to Improve The \\ Oxidative Resistance of Cooking Oil
}

\author{
Posman Sibuea $^{1)}$, Devi Oktavia Tambunan ${ }^{2)}$ dan Maruba Pandiangan ${ }^{3)}$ \\ ${ }^{1,2,3}$ Program Studi Teknologi Hasil Pertanian, UNIKA Santo Thomas Medan \\ email : posman_sibuea@yahoo.com
}

\begin{abstract}
This research was intended to study the effectiveness of andaliman extract and storage time on the oxidative value of cooking oil. The research was carried out at the Food Processing Laboratory of the Catholic University of Santo Thomas, Medan. This experiment was performed with using completely randomized design (CRD) faktorial, that consist of two treatment factors. The first factor was the concentration of the extract andaliman code $K$, consisting of 5 levels, namely: $K_{0}=0 \mathrm{ppm}, K_{1}=200 \mathrm{ppm}, K_{2}=400$ $\mathrm{ppm}, K_{3}=600 \mathrm{ppm}, K_{B H T}=200 \mathrm{ppm}(\mathrm{wt} / \mathrm{vol})$. The second factor is the storage time $(L)$, with 4 levels, namely: $L_{1}=0$ days, $L_{2}=7$ days, $L_{3}=14$ days, $L_{4}=21$ days. Data analysis was carried out by using the LSR (Least Significant Ranges) test. The results showed that the andaliman extract had a significant effect on free fatty acids, peroxide number and viscosity. The storage time has an effect the higher the peroxide level and the viscosity level, but the free fatty acid levels decreased. The combination of treatment andaliman extract concentration and storage time_showed no significant difference in the observed parameters. The oxidative resistance of andaliman extract at $K_{1}$ was $40.38 \%, K_{2}$ was $45.20 \%, K_{3}$ was $49,05 \%$ and $K_{B H T}$ as a comparison was $54,55 \%$ indicating the amount of antioxidant activity. The best concentration of andaliman extract was obtained at $K_{3}$ (600 ppm) with a storage time of 3 weeks
\end{abstract}

Keywords : andaliman extract, antioxidant activity, peroxide number

\begin{abstract}
ABSTRAK
Penelitian ini bertujuan untuk mempelajari efektivitas ekstrak andaliman dan lama penyimpanan terhadap nilai oksidatif minyak goreng. Penelitian dilakukan di Laboratorium Pengolahan Pangan Universitas Katolik Santo Thomas, Medan. Penelitian ini dilakukan dengan menggunakan Rancangan Acak Lengkap (RAL) faktorial yang terdiri dari dua faktor perlakuan. Faktor pertama adalah konsentrasi ekstrak andaliman kode $\mathrm{K}$ yang terdiri dari 5 taraf yaitu: $\mathrm{K} 0=0 \mathrm{ppm}, \mathrm{K} 1=200$ ppm, K2 $=400 \mathrm{ppm}, \mathrm{K} 3=600 \mathrm{ppm}, \mathrm{KBHT}=200 \mathrm{ppm}(\mathrm{wt} / \mathrm{vol})$. Faktor kedua adalah lama penyimpanan (L), dengan 4 taraf yaitu: L1 $=0$ hari, L2 $=7$ hari, L3 $=14$ hari, L4 $=21$ hari. Analisis data dilakukan dengan menggunakan uji LSR (Least Significant Ranges). Hasil penelitian menunjukkan bahwa ekstrak andaliman berpengaruh nyata terhadap asam lemak bebas, bilangan peroksida dan viskositas. Lama penyimpanan berpengaruh semakin tinggi tingkat peroksida dan tingkat viskositas, tetapi kadar asam lemak bebas semakin menurun. Kombinasi perlakuan konsentrasi ekstrak andaliman dan lama penyimpanan tidak menunjukkan perbedaan yang
\end{abstract}

Efektivitas Ekstrak Andaliman (Zanthoxylum Acanthopodium Dc.) untuk Meningkatkan Daya Tahan 49 Oksidatif Minyak Goreng, Oleh : Posman Sibuea, Devi Oktavia Tambunan, Maruba Pandiangan 
signifikan pada parameter yang diamati. Ketahanan oksidatif ekstrak andaliman pada K1 sebesar 40,38\%, K2 sebesar 45,20\%, K3 sebesar 49,05\% dan KBHT sebagai pembanding sebesar 54,55\% yang menunjukkan besarnya aktivitas antioksidan. Konsentrasi ekstrak andaliman terbaik diperoleh pada K3 (600 ppm) dengan lama penyimpanan 3 minggu

Kata kunci : Ekstrak andaliman, aktivitas antioksidan, bilangan peroksida

\section{PENDAHULUAN}

Minyak goreng sangat dibutuhkan untuk pengolahan makanan. Kebutuhan minyak goreng pun semakin meningkat seiring dengan bertambahnya jumlah penduduk dan dampaknya minyak goreng bekas yang dihasilkan semakin meningkat pula (Sibuea, 2015).

Perekonomian yang semakin baik belakangan ini memberi kosekuensi logis semakin tingginya penggunaan minyak goreng. Konsumsi yang semakin meningkat akan menghasilkan minyak goreng bekas dari sisa rumah tangga dan restoran. Namun, harga minyak goreng yang semakin mahal menuntut perlu dilakukan upaya untuk memanfaatkan kembali minyak goreng tersebut agar tidak terbuang dan mencemari lingkungan. Pemanfaatan minyak goreng bekas ini dilakukan dengan pemurnian dengan menggunakan arang aktif sehingga memenuhi mutu minyak goreng yang baik.

Selain itu, penggunaan antioksidan untuk menghambat laju oksidasi semakin penting untuk meningkatkan daya tahan oksidatif minyak goreng. Antioksidan merupakan senyawa yang dalam jumlah relatif sedikit mampu menghambat proses oksidasi dalam bahan pangan. Ia mengakhiri reaksi berantai radikal bebas seperti radikal hidoksil, radikal hidroperoksil, radikal peroksil dan radikal alkosil melalui pemberian hidrogen atau elektron kemudian mengubahnya menjadi poduk yang lebih stabil (Sibuea, 2002; 2005; Min and Boff, 2002).

Andaliman

(Zanthoxylum

acanthopodium DC) merupanan jenis tanaman perdu yang memiliki buah bulat hijau kecil seperti lada. Buahnya jika digigit

mengeluarkan aroma wangi dan rasa tajam yang khas dan dikenal pemberi rasa spesifik pada masakan batak. Tingginya aktivitas antioksidan andaliman menjanjikan prospek yang sangat baik untuk dikembangkan apalagi saat ini sebagian besar masyarakat perkotaan memiliki kecendrungan untuk menjalani gaya hidup sehat kembali ke alam (Sibuea, 2013).

Penggunaan antioksidan alami akan makin meningkat pada masa mendatang mengingat rasa khawatir masyarakat pada efek samping yang ditimbulkan antioksidan sintetik seperti BHA, BHT, propil galat dan lain-lain, yaitu kanker hati dan aneka jenis penyakit lainnya (Sibuea, 2013).

Tujuan penelitian ini untuk melihat pengaruh ekstrak andaliman dan lama penyimpanan terhadap daya tahan oksidatif minyak goreng bekas. Manfaatkan kembali minyak goreng bekas agar tidak terbuang menjadi topik penelitian yang menarik. Ekstrak andaliman mengandung senyawa fitokimia yang berperan sebagai antioksidan alami untuk menangkap radikal bebas dan mengkuensing oksigen singlet.

\section{METODE PELAKSANAAN}

\section{Bahan}

Bahan yang digunakan adalah minyak goreng bekas dari penjual gorengan, arang aktif, dan buah andaliman yang diperoleh dari Sidikalang, aquadest, alkohol 
$96 \%, \mathrm{KOH} 0,1 \mathrm{~N}$, asam asetat, kloroform, larutan KI jenuh, phenolphthalein (pp), larutan pati $1 \%$, dan $\mathrm{Na}_{2} \mathrm{~S}_{2} \mathrm{O}_{3} 0,1 \mathrm{~N}$.

\section{Alat}

Alat yang digunakan adalah erlenmeyer, gelas ukur, buret, pipet mohr, penangas air, kertas saring, beaker glass, blender, alat destilasi, corong, timbangan analitis, pipet tetes, botol, kromatografi kolom, freeze dryer dan vakum rotary evaporator.

\section{Pembuatan Ekstrak Andaliman}

Andaliman yang telah disiapkan dicuci dengan air bersih yang mengalir, ditiriskan, kemudian di freeze drying (temperatur $=-40^{\circ} \mathrm{C}$ ) selama dua hari. Andaliman sebanyak $20 \mathrm{~g}$ dihancurkan dengan "waring blender", bubuk andaliman yang diperoleh lalu direndam dengan $150 \mathrm{ml}$ pelarut organik etanol dan ditutup dan dibiarkan selama 5 hari.

Perendaman dihindari dari kontak cahaya sambil diaduk berulang-ulang. Perendaman dilanjutkan dan pengambilan filtrat dilakukan dengan cara penyaringan. Residu andaliman direndam kembali dengan etanol sampai diperoleh filtrat jernih yang tidak berwarna.

Pemekatan ekstrak dilakukan dengan vacuum rotary evaporator dan dikeringkan dengan freeze dryer (Suhu $-40^{\circ} \mathrm{C}$ ) selama dua hari. Pemurnian minyak goreng bekas dilakukan dengan metode Sibuea, dkk (2005).

\section{Prosedur Penelitian}

Ekstrak andaliman yang terlah diperoleh dengan metode maserasi ditambahkan ke dalam $20 \mathrm{ml}$ minyak goreng bekas yang telah dimurnikan dengan arang aktif yang telah disiapkan sebelumnya. Penambahan ekstrak andaliman sesuai dengan perlakuan 0, 200, 400, 600 ppm (wt/vol) pada temperatur kamar. Lama penyimpanan dilakukan sesuai dengan perlakuan $(0,7,14,21$ hari). Selanjutnya dilakukan pengujian efektivitas ekstrak andaliman terhadap daya tahan oksidatif minyak goreng bekas dengan menganalisa asam lemak bebas (Sudarmadji dkk, 2004), bilangan peroksida (Sudarmadji dkk, 2004), Viskositas (Sudarmadji dkk, 2004), dan penghambatan oksidatif (Sibuea, 2015).

\section{HASIL DAN PEMBAHASAN}

Penelitian yang bertujuan untuk mengetahui efektivitas ekstak andaliman terhadap daya tahan oksidatif minyak goreng bekas, secara umum hasil penelitian menunjukkan bahwa konsentrasi ekstrak andaliman dan lama penyimpanan berpengaruh terhadap daya tahan oksidatif minyak goreng bekas yang diamati seperti disajikan pada Tabel 1.

Dari Tabel 1 dapat dilihat bahwa semakin tinggi konsentrasi ekstrak andaliman maka persen penghambat oksidatif dan viskositas semakin meningkat sedangkan asam lemak bebas dan angka peroksida semakin menurun. Derajat penghambatan oksidatif yang makin meningkat adalah efek positif dari ekstrak andaliman untuk menahan laju angka peroksida sehingga tidak meningkat.

Dari Tabel 2 dapat dilihat bahwa semakin lama penyimpanan maka angka peroksida, viskositas, dan $\%$ penghambat oksidatif semakin meningkat sedangkan asam lemak bebas semakin menurun. Peningtan angka peroksida dapat dipahami bahwa semakin lama minyak disimpan maka reaksi oksidatif yang terjadi pada minyak semakin intensif terjadi. Lama penyimpan akan dapat meningkatkan laju oksidatif pada makanan yang mengandung minyak.

\section{Analisa Asam Lemak Bebas}

Asam lemak bebas adalah asam lemak yang berada sebagai asam bebas tidak terikat sebagai trigliserida. Menurut Sutiah dkk (2008) uap air yang dihasilkan pada saat proses penggorengan menyebabkan terjadinya hidrolisis terhadap trigliserida, menghasilkan asam lemak bebas dan gliserol yang diindikasikan dengan bilangan asam. 
Berdasarkan Standar Nasional Indonesia syarat mutu bilangan asam minyak goreng yang baik adalah maksimal $0,6 \mathrm{mg} \mathrm{NaOH} / \mathrm{g}$. Penambahan ekstrak

Tabel 1. Pengaruh Konsentrasi Ekstrak Andaliman terhadap parameter yang diamati

\begin{tabular}{lcccc}
\hline $\begin{array}{c}\text { Konsentrasi } \\
\text { Ekstrak }\end{array}$ & $\begin{array}{c}\text { Asam } \\
\text { Aemak } \\
\text { Andaliman }(\mathrm{ppm})\end{array}$ & $\begin{array}{c}\text { Angka } \\
\text { Peroksida } \\
\text { Bebas }(\%)\end{array}$ & $\begin{array}{c}\text { Viskositas } \\
(\mathrm{cps})\end{array}$ & $\begin{array}{c}\text { Penghambatan } \\
\text { Oksidatif }(\%)\end{array}$ \\
\hline $\mathrm{K}_{0}=0 \mathrm{ppm}$ & 0,57 & 5,57 & 73,15 & 39,93 \\
$\mathrm{~K}_{1}=200 \mathrm{ppm}$ & 0,60 & 4,12 & 73,95 & 40,38 \\
$\mathrm{~K}_{2}=400 \mathrm{ppm}$ & 0,56 & 3,52 & 75,02 & 45,30 \\
$\mathrm{~K}_{3}=600 \mathrm{ppm}$ & 0,55 & 3,06 & 76,02 & 49,05 \\
$\mathrm{~K}_{\mathrm{BHT}}=200 \mathrm{ppm}$ & 0,55 & 2,15 & 76,39 & 54,55 \\
\hline
\end{tabular}

*Uji rata-rata Duncan menunjukkan berbeda nyata $(\mathrm{p}<0,05)$

Tabel 2. Pengaruh Lama Penyimpanan terhadap parameter yang diamati

\begin{tabular}{ccccc}
\hline $\begin{array}{c}\text { Lama } \\
\text { Penyimpanan } \\
\text { (Minggu) }\end{array}$ & $\begin{array}{c}\text { Asam Lemak } \\
\text { Bebas }(\%)\end{array}$ & $\begin{array}{c}\text { Angka } \\
\text { Peroksida } \\
(\mathrm{meg} / \mathrm{kg})\end{array}$ & $\begin{array}{c}\text { Viskositas } \\
(\mathrm{cps})\end{array}$ & $\begin{array}{c}\text { Penghambatan } \\
\text { Oksidatif } \\
(\%)\end{array}$ \\
\hline $\mathrm{L}_{0}(0)$ & 0,57 & 2,94 & 74,50 & 47,66 \\
$\mathrm{~L}_{1}(1)$ & 0,57 & 3,47 & 74,62 & 46,65 \\
$\mathrm{~L}_{2}(2)$ & 0,56 & 3,81 & 74,89 & 44,45 \\
$\mathrm{~L}_{3}(3)$ & 0,55 & 4,26 & 75,15 & 43,85 \\
\hline
\end{tabular}

*Uji rata-rata Duncan menunjukkan berbeda nyata $(\mathrm{p}<0,05)$

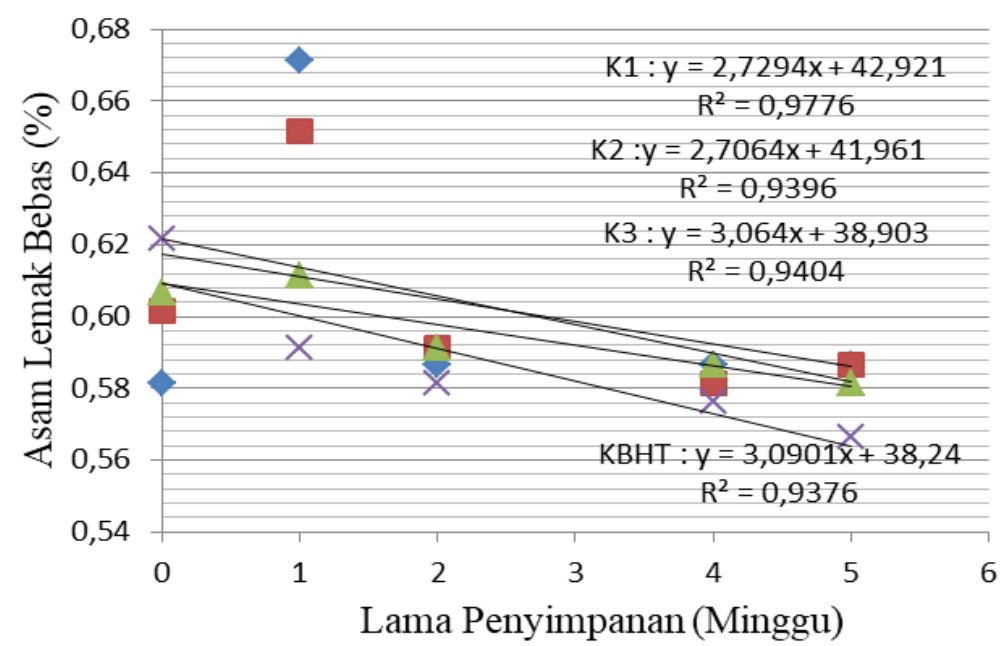

Gambar 1. Hubungan Konsentrasi EkstrakAndaliman dan Lama Penyimpanan Asam Lemak Bebas Minyak Goreng Bekas

Dari Gambar 1 dapat dilihat hasil analisa asam lemak bebas minyak goreng bekas yang telah diberi perlakuan dengan variasi lama penyimpanan. Gambar 1 menunjukkan bahwa semakin tinggi konsentrasi ekstrak andaliman dapat menurunkan pemebentukan asam lemak minyak goreng selama penyimpanan. Sedangkan lama penyimpanan dapat menaikkan jumlah asam lemak bebas. Hal ini disebabkan pada sampel minyak goreng bekas masih mengandung sejumlah air dari kontaminasi bahan yang digoreng sebelumnya dan dikarenakan uap air yang 
terbentuk selama proses penggorengan, sehingga mempercepat reaksi hidrolisis. Asam lemak bebas tertinggi terdapat pada kombinasi perlakuan $\mathrm{K}_{1} \mathrm{~L}_{0}$ sebesar $0,67 \%$ dan terendah pada kombinasi perlakuan $\mathrm{K}_{\mathrm{BHT}} \mathrm{L}_{3}$ sebesar $0,57 \%$.

Dari Gambar 2 menunjukkan bahwa angka peroksida pada perlakuan penambahan ekstrak andaliman mengalami penurunan. Hal ini disebabkan antioksidan yang terdapat pada ekstrak andaliman dapat menghambat reaksi oksidasi pada minyak goreng bekas yang ditandai dengan angka peroksida yang makin menurun. Gambar 2 juga menunjukkan bahwa angka peroksida cenderung mengalami kenaikan seiring lamanya waktu penyimpanan. Kecenderungan peningkatan bilangan peroksida ini menunjukkan bahwa minyak mengalami kerusakan selama reaksi oksidasi akibat terbentuknya senyawa peroksida. Kerusakan senyawa antioksidan yang digunakan seiring bertambahnya lama waktu penyimpanan diduga sudah terjadi sehingga dapat mengurangi efektivitas antioksidan untuk menghambat laju pembentukan senyawa peroksida yang terkandung dalam minyak goreng bekas (Min and Boff. 2002; Sibuea, dkk. 2005; Evika, 2011 ).

\section{Viskositas}

Viskositas adalah ukuran yang menyatakan kekentalan suatu cairan atau fluida. Kekentalan merupakan sifat cairan yang berhubungan erat dengan hambatan untuk mengalir. Peningkatan viskositas minyak goreng dapat dilihat pada Gambar 3 .

Pada Gambar 3 dapat dilihat bahwa semakin lama penyimpanan maka viskositas minyak goreng bekas semakin meningkat. Fenomena ini disebabkan minyak goreng bekas yang telah dimurnikan dan ditambahkan ekstrak andaliman mampu meningkatkan kenaikan viskositas. Minyak goreng yang belum dipakai mempunyai nilai viskositas yang paling besar karena minyak tersebut kerapatannya lebih besar karena belum mengalami pemanasan sehingga gesekan yang terjadi antara lapisan-lapisan dalam minyak tersebut lebih besar dan viskositasnya juga besar. Viskositas dalam cairan ditimbulkan oleh gesekan dalam lapisan-lapisan dalam cairan, sehingga makin besar gesekan yang terjadi maka viskositasnya semakin besar, begitu juga jika gesekan yang terjadi lebih kecil, maka viskositasnya juga kecil.

Menurut Sutiah et.al. (2008) bahwa nilai viskositas terbesar terdapat pada minyak goreng yang belum pernah dipakai. Minyak goreng bekas yang telah dimurnikan mengalami peningkatan nilai viskositas seiring dengan peningkatan konsentarsi ekstrak andaliman. Selama Penyimpanan antioksidan ekstrak andaliman berikatan dengan senyawa peroksida yang dihasilkan dari proses oksidasi lemak yang menyebabkan meningkatnya daya tahan oksidatif minyak goreng (Sibuea, 2015).

\section{Penghambatan Oksidatif}

Salah satu parameter penting minyak goreng adalah angka peroksida. Semakin tinggi kandungan peroksida dalam minyak goreng mutunya semakin menurun. Hasil penelitian menunjukkan penambahan ekstrak andaliman memberi pengaruh signifikan pada penurunan angka peroksida dan peningkatan daya tahan oksidatif minyak goreng seperti pada Gambar 4 .

Dari Gambar 4 menunjukkan bahwa semakin meningkat konsentrasi ekstrak andaliman maka persen penghambatan oksidatif semakin meningkat. Peningkatan persen penghambatan oksidatif karena ekstrak andaliman mengandung senyawa fenolik sehingga mampu menghambat kerusakan minyak akibat reaksi oksidasi. Pada proses penghambatan oksidatif, senyawa antioksidan bekerja dengan cara mendonorkan atom hidrogen untuk menghambat proses autooksidasi dan dapat mengurangi kerusakan minyak goreng karena serangan oksigen singlet dan triplet (Min anf Boff, 2002; Sibuea, dkk., 2005). 
Selama penyimpanan minyak goreng, antioksidan akan berikatan dengan senyawa peroksida pada proses oksidasi dan menghasilkan minyak yang memiliki daya tahan oksidatif yang semakin tinggi. Pada

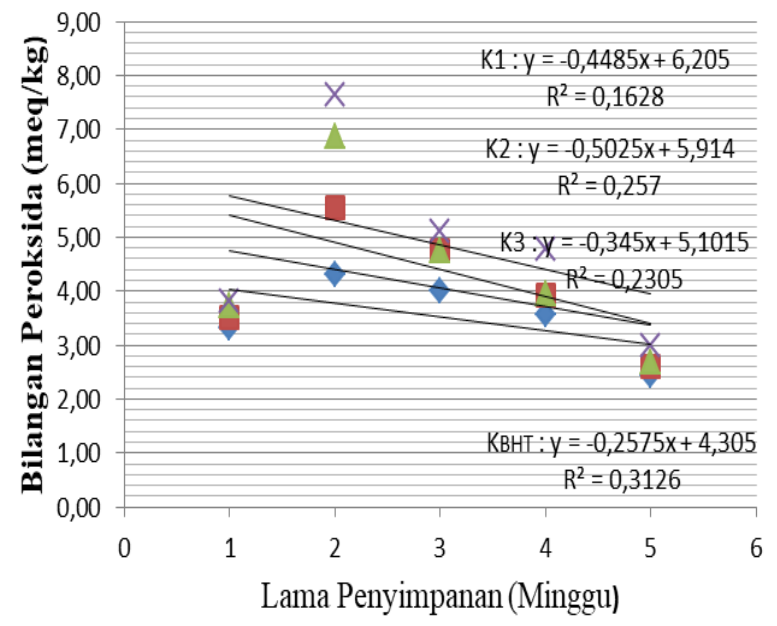

Gambar 2. Hubungan konsentrasi ekstrak andaliman dan lama penyimpanan terhadap bilangan peroksida minyak goreng bekas

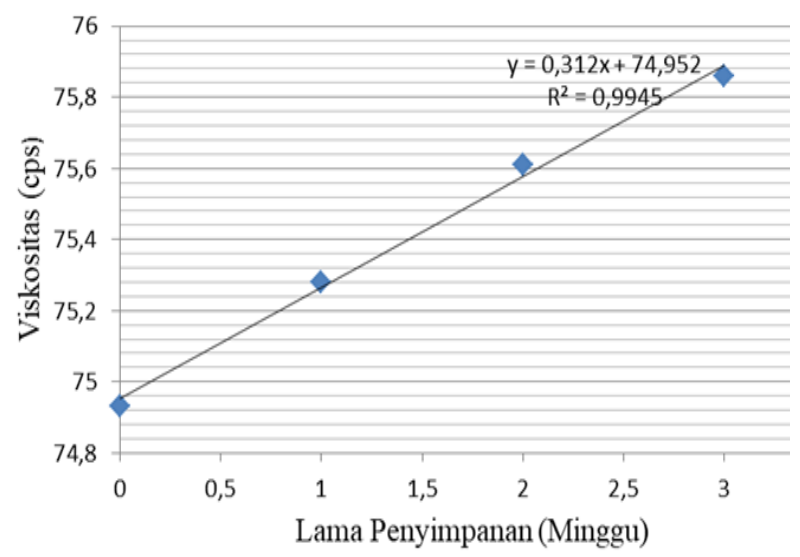

Gambar 3. Hubungan Lama Penyimpanan dengan Viskositas Minyak Goreng Bekas

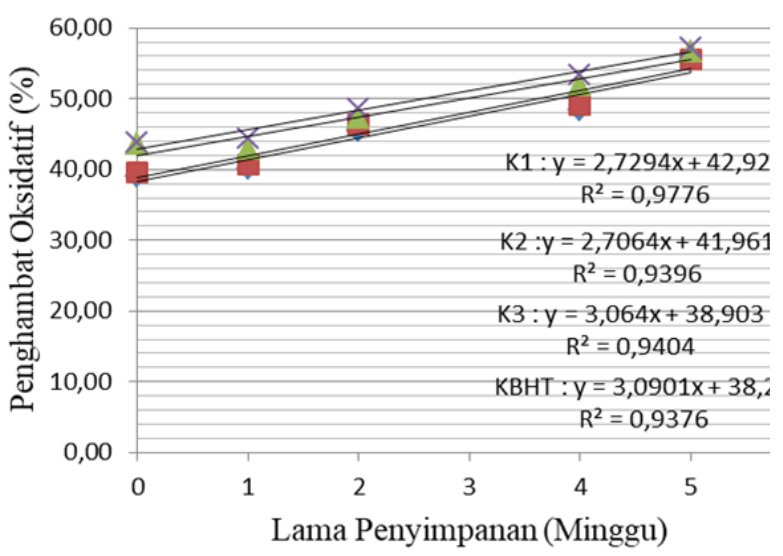

penyimpanan yang makin lama, pembentukan senyawa hidroperoksida dapat ditekan dengan penambahan ekstrak andaliman dan ketengikan dalam minyak goreng bekas dapat dihambat.

Gambar 4. Hubungan Konsentrasi Ekstrak Andaliman dan Lama Penyimpanan terhadap persen Penghambatan Oksidatif Minyak Goreng Bekass

\section{KESIMPULAN}

1. Konsentrasi ekstrak andaliman memberi pengaruh berbeda nyata $(\mathrm{P}<0,05)$ terhadap asam lemak bebas, bilangan peroksida, persen penghambatan oksidatif, dan viskositas. Semakin tinggi konsentrasi ekstrak andaliman, persen penghambatan oksidatif dan viskositas semakin meningkat. Sedangkan asam lemak bebas dan bilangan peroksida semakin menurun.

2. Lama penyimpanan memberi pengaruh berbeda nyata $(\mathrm{P}<0,05)$ terhadap asam lemak bebas, bilangan peroksida, viskositas, dan persen penghambatan oksidatif. Semakin lama penyimpanan bilangan Konsentrasi ekstrak andaliman memberi pengaruh berbeda nyata $(\mathrm{P}<0,05)$ terhadap asam lemak bebas, bilangan peroksida, persen penghambatan oksidatif, dan viskositas. Semakin tinggi konsentrasi ekstrak andaliman, persen penghambatan oksidatif dan viskositas semakin meningkat. Sedangkan asam lemak bebas dan bilangan peroksida semakin menurun.

3. Lama penyimpanan memberi 
pengaruh berbeda nyata $(\mathrm{P}<0,05)$ terhadap asam lemak bebas, bilangan peroksida, viskositas, dan persen penghambatan oksidatif. Semakin lama penyimpanan bilangan peroksida, viskositas dan persen penghambatan oksidatif semakin meningkat, sedangkan asam lemak bebas semakin menurun.

4. Kombinasi perlakuan konsentrasi ekstrak andaliman dengan lama penyimpanan memberi pengaruh tidak berbeda sangat nyata $(\mathrm{p}>0.01)$ terhadap persen penghambatan

\section{DAFTAR PUSTAKA}

Evika. 2011. Penggunaan Adsorben Arang Aktif Tempurung Kelapa Pada Pemurnian Minyak Goreng Bekas. Skripsi Universitas Islam Negeri Sultan Syarif Kasim, Riau

Kathleen O, Anja H, Heiko S, and Karin S. 2010. Impact of emulsifier microenvironments on acid-base equilibrium and activity of antioxidants. Journal of Food Chemistry (118), 48-55

Ketaren, S, 1986. Pengantar Teknologi Minyak dan Lemak Pangan. Jakarta: UI Press Min, D.B and J.M. Boff. 2002. Chemistry and Reaction of Singlet Oxygen in Foods. Comp. Rev. Food Sci. and Food Safety. (1): $58-72$

Sibuea, P. 2002. Potensi Andaliman sebagai Antioksidan Alami. Kompas, Jakarta

Sibuea, P. 2004. Antioksidan, Senyawa Ajaib Penangkal Penuaan Dini. Sinar Harapan. Jakarta.

Sibuea, P., Raharjo, S. Santoso, U., dan Noor, Z. 2005. Mekanisme dan Kinetika Quenching Kuersetin oksidatif, asam lemak bebas, bilangan peroksida dan viskositas minyak goreng.

5. Konsentrasi ekstrak andaliman terbaik diperoleh pada kombinasi perlakuan $\mathrm{K}_{3} \mathrm{~L}_{1}$, yakni penambahan ekstrak andaliman 600 ppm dan lama penyimpanan 7 hari.

Terhadap Efek Fotosensitisasi Pewarna Makanan Sintetik Eritrosin dalam Oksidasi Minyak Sawit Jurnal Teknologi dan Industri Pangan (16): 103 - 112. IPB Bogor

Sibuea, P. 2013. Fungsi Makanan Untuk Kesehatan; Perspektif Baru Antioksidan Alami untuk Gaya Hidup Sehat. Bina Media Perintis. Medan

Sibuea, P. 2015. Minyak Kelapa Sawit: Teknologi dan Manfaatnya untuk Pangan Nutrasetikal. Erlangga, Jakarta.

SNI - 3741 - 1995. Standar Mutu Minyak Goreng. Jakarta.

Sudarmadji, S., Haryono., B dan Suhardi, 2004. Prosedur Analisa untuk Bahan Makanan dan Pertanian. Liberty, Yogyakarta

Sutiah, S., Firdausi, K. S dan Budi, W. S. 2008. Studi kualitas minyak goreng dengan parameter viskositas dan indeks bias. Berkala Fisika, 11(2), 53-58 